\title{
THE SYRIAC LIFE OF JOHN OF TELLA AND THE FRONTIER POLITELA ${ }^{\dagger}$
}

\author{
NATHANAEL J. ANDRADE \\ UNIVERSITY OF MICHIGAN
}

\begin{abstract}
After the Syrian bishop John of Tella died in 538 C.E., his disciple Elias wrote his hagiography and recounted his ministry of priestly ordinations within the frontier zone of Rome and Persia. Elias and other contemporary anti-Chalcedonians of Syria conceived of the network of priests and ascetics that John created along the frontier as a politeia, a society that could transcend the imperial boundaries that divided Roman and Persian territories. Elias' viewpoints are thereby significant in showing how John's partisans understood his ministry, and they demonstrate how John's politeia could be regarded as a viable alternative to participating in imperial systems that sustained idolatrous behavior.
\end{abstract}

\section{INTRODUCTION}

In the early sixth century C.E., the bishop John of Tella struggled with Ephrem, the Chalcedonian patriarch of Antioch, over their definitions of Christian orthodoxy. ${ }^{1}$ Two stark contrasts within the

t I offer my gratitude to Ray Van Dam, John Fine, and the anonymous reviewers for their helpful comments and criticisms, as well as to 
region, one political and the other religious, strongly affected the terms of their debate. First, two political entities hotly contested the region where John spent his life. The Persian victory over the emperor Julian's army in 363 had restored Nisibis and many Mesopotamian territories that Rome had controlled at that time to the Persians, and it had offered further hope that they might retake other territories previously lost. After a period of relative peace, in the late fifth and throughout the sixth centuries, the Persian and Roman empires waged numerous wars along their frontier zone in Mesopotamia. Many of these wars were centered on the definition of an administrative and imperially contrived boundary dividing the Roman and Persian empires. ${ }^{2}$ Second, after 518, the emperors Justin and Justinian had decided to uphold the doctrine of a Christ with two natures espoused by the Council of Chalcedon, and the "Chalcedonians" who supported the council were thereby encouraged to persecute their doctrinal opponents, the "antiChalcedonians.".3 John of Tella, one of the anti-Chalcedonian dis-

Eric Reymond, who advised me on matters of Syriac translation. Parts of this essay were presented at the Near and Middle Eastern Civilizations Graduate Student Symposium at the University of Toronto, March 2, 2006 and the 4th Annual Greek and Latin Graduate Student Colloquium at The Ohio State University, April 15, 2006. I thank the participants for their comments. All mistakes are my own.

${ }^{1}$ For a concise description of John's life and activities, see the prosopography of E. Honigmann, Évêques et évêchés Monophysites d'Asie antérieure au Vle siècle, CSCO 127/Subsidia 2 (Louvain: Secrétariat du CorpusSCO, 1951), 51-2. The city of Tella, also called Constantia or Constantina, was located in the Roman province of Mesopotamia.

2 The unrelenting effort to define the extent of Roman and Persian territory, one characteristic of Justinian's reign, is usefully formulated by Geoffrey Greatrex, "Byzantium and the East in the Sixth Century," in The Cambridge Companion to the Age of Justinian, ed. Michael Maas (Cambridge: Cambridge University Press, 2005), 490. In this essay, I will use the term "Syria" to refer generically to the region that consisted of the Roman provinces of Syria Prima, Syria Secunda, Euphratensis, Mesopotamia, and Osrhoene. I will also make references to "Roman Mesopotamia" and "Persian Mesopotamia" to describe the regions between the Tigris and Euphrates rivers under the theoretical control of Rome or Persia. These terms are to be distinguished from the specific Roman province of Mesopotamia.

3 The propriety of using the term "Monophysite" has been challenged over the last few decades, and Sebastian Brock, for instance, states that Severus of Antioch and his supporters should be classified as "henophysite" or "miaphysite." See Sebastian Brock, "The Christology of the Church of the East in the Synods of the Fifth to the Early Seventh Centu- 
senters within Syria, was deprived of his episcopal see by his opponents in 521, and he subsequently relocated to the frontier zone with numerous other persecuted clergymen and monks. It was there that he began to ordain priests and to circulate his own written canons to clerics presiding over village congregations. ${ }^{4}$ His efforts served as a starting point for the gradual development of a dissenting anti-Chalcedonian clerical hierarchy and ultimately a separatist church of "Syrian Orthodox," a development which was stimulated by the activity of Jacob Baradeus (Bardeāyā) after 542 and which gained momentum over the following century. ${ }^{5}$

Some time after 542, an author named Elias wrote John's hagiography in Syriac. ${ }^{6}$ The Life of John of Tella consists of an exten-

ries," in Aksum-Thyateira, a Festschrift for Archbishop Methodius, ed. G. Dragas (London, 1985), 132 and "The 'Nestorian' Church: A Lamentable Misnomer," (BJRL 78.3 [1996]), 26. In this essay, I will use the term "antiChalcedonian" which, although not a theologically based label, does adequately encapsulate the opposition to the Council of Chalcedon which served as a rallying point for clerics and monks like John of Tella. It is also a convenient term to use for the opponents of the council of Chalcedon within Syria before the development of a separate "Syrian Orthodox" church with a fully developed and autonomous clerical hierarchy. However, see the objections raised to the term "anti-Chalcedonian" by Volker Menze, Justinian and the Making of the Syrian Orthodox Church (Oxford: Oxford University Press, 2008), 2-3.

${ }^{4}$ According to Volker Menze, "Priests, Laity, and the Sacrament of the Eucharist in Sixth-Century Syria" (Hugoye, Journal of Syriac Studies 7:2 [2004]), par. 6, John had circulated his canons in order to educate the many relatively inexperienced priests that he had ordained.

5 The gradual formation of a separate hierarchy after John's death, largely driven by the activity of Jacob Baradeus (Bard'āyā), is described by Lucas Van Rompay, "Society and Community in the Christian East," in The Cambridge Companion to the Age of Justinian, ed. Michael Maas (Cambridge: Cambridge University Press, 2005), 248-52. See Menze, Justinian, 145-93 for the role that the generation of John of Tella played.

6 The name Elias corresponds to the Hebrew Elijah, which scholars sometimes use to describe this author. The author provides the consonantal structure of this name ( $\mathbf{s} \boldsymbol{\sim})$ in Vita Iobannis Episcopi Tellae 31. The Peshitta Gospels, such as Matt 11:14, Mark 9:4-5, and Luke 9:8, provide paradigms for vocalizing the name. See Tetraenangelium Sanctum juxta simplicem Syrorum versionem ad fidem codicum, massorae, editionum denuo regcognitum, ed. P. E. Pusey and G. H. Gwilliam (Oxford: Clarendon Press, 1901), 70, 250, and 374. However, I will refer to the author as Elias in order to be consistent with how most previous scholars have referred to him and therefore to avoid confusion. In Vita Iohannis Episcopi Tellae 38-9, the author refers to the Persian sacking of John's native city of Callinicum in 
sive letter that Elias addressed to certain anti-Chalcedonian faithful during the hardships that arose after John's death in 538, and it was clearly intended to encourage them to persist in their faith amid persecution and uncertainty. The letter, which follows many of the conventions of the hagiographical genre, depicted John as an unwavering proponent of Severus of Antioch and his doctrines in the face of Chalcedonian persecution. ${ }^{7}$ Severus, the deposed bishop of Antioch, advocated a theological position in which Christ was understood to have one incarnate nature, but after Severus' deposition in 518, John emerged as a leading proponent of his doctrinal outlook in the borderlands of Rome and Persia. ${ }^{8}$ Over the course of his letter, Elias casts himself as a personal disciple of John who went to the same extremes as his mentor in his resistance to imperial mandates. Elias, however, is a shadowy figure, virtually unre-

542, which provides the earliest possible date for his Life. The standard edition for the text is still Vita Iohannis Episcopi Tellae, ed. and tr. by E. W. Brooks in Vitae virorum apud Monophysitas, CSCO III 25 (7-8) (Paris: E Typographeo Reipublicae, 1907), 29-95 and 21-60 (for his Latin translation). The only extant English translation of the text is The Biography of John of Tella by Elias, trans. J. R. Ghanem (Diss. University of Wisconsin, 1970). For an extremely helpful analysis of Elias' literary technique and his authorial persona, see Andrew Palmer, "Saints' Lives with a Difference: Elijah on John of Tella (d. 538) and Josephus on Theodotos of Amida (d. 698)," in IV Symposium Syriacum 1984: Literary Genres in Syriac Literature, ed. H. J. W. Drijvers et al., Orientalia Christiana Analecta 229, 203-16. Also valuable is Menze, Justinian, 229-35.

${ }^{7}$ In fact, the author may have been trying to dispel rumors that John had converted to the Chalcedonian position. According to the Vita Iohannis Episcopi Tellae 82, 91-2, during the disputation held at Reshaina shortly after John's abduction from Singara, John's opponents had ostensibly tricked him into admitting that Christ had two natures. John had cited a passage from Cyril, Epistulae 45 (PG 77, c. 232), in which Cyril affirmed that the human mind could comprehend the existence of two natures before the Union but then stressed that only one nature could be discerned after it. However, John's enemies rose into a clamor before he could present the second part of Cyril's argument and claimed that John had admitted that Christ had two natures. Elias was clearly embarrassed by this development and stressed that John had not departed from how Severus of Antioch interpreted Cyril's theology. In fact, he asserts that John claimed that Severus was his "head" (85).

${ }^{8}$ For Severus' theological formulations, see Roberta C. Chesnut, Three Monophysite Christologies: Severus of Antioch, Philoxenus of Mabbug, and Jacob of Sarug (Oxford: Oxford University Press, 1976), 9-56. Refer to Pauline Allen and C. T. R. Hayward, Severus of Antioch (London: Routledge, 2004), 34-8 for a concise summary. 
corded in sources of this period. According to his own testimony, he had lived with John on the mountain of Singara, and he claimed that both he and John had been abducted by Ephrem and brought together to Antioch, where John died the following year. ${ }^{9}$ Yet, it is difficult to gauge the reliability of Elias's description of his relationship with John. His claim that he had personally witnessed the events that he described, in addition to his statement that he had consulted John's mother, tutor, and other friends to obtain reliable information, could easily reflect an effort to establish his authoritative voice as narrator and to work within the normative conventions of the hagiographical genre. ${ }^{10} \mathrm{He}$ may not have been as close a friend and disciple to John of Tella as he claims.

Yet, Elias' Life is an important text because it reflects an effort to frame the significance of John's ministry during the years of tribulation that followed John's death. Much like the Life of John written by John of Ephesus, Elias' letter depicts John of Tella as the leader and linchpin of a clerical hierarchy and a network of priests and monks that cut across the frontier of the Roman and Persian empires. ${ }^{11}$ Both Lives in fact described John as a liminal figure who imagined a community that could incorporate the dispossessed and persecuted of two separate empires. At the same time, while Elias depicted John as the creator of a true Christian politeia, he defended John against charges of treason that he claimed to have been leveled against him by both Roman and Persian authorities, who had likened John to a bandit and a social outsider. For this reason, the author claimed that Ephrem, the bishop of Antioch, had conspired with Persian magistrates to have him kidnapped from the Persian wilderness, and he endeavored to explain

9 The author inserts himself into his narrative of John's captivity in Vita Iohannis Episcopi Tellae when he claims that on one occasion their pagan abductor Cometas told "us" that he had sacrificed a bull before coming to torment them (67) and when he claims that he witnessed the miracles that the monk Heliodorus had performed during John's captivity in Antioch (92-3). Andrew Palmer, "Saints' Lives with a Difference," 209_ 11 convincingly argues that the author's vivid details of the Persian attack on John's community and his interrogation at Nisibis by the Marzban indicate "the presence of the author" (210).

10 Vita Iohannis Episcopi Tellae 38, 43.

11 John of Ephesus includes a biography of John of Tella within his Lives of the Eastern Saints 24, ed. and tr. by E. W. Brooks, PO 18 (Paris: Firmin-Didot, 1924), 513-26 [312-24]. According to the testimony of John of Ephesus, he was ordained deacon by John of Tella in 529. See Lives of the Eastern Saints 24 (Life of John of Thella), 521 [319]. 
why the creation of John's politeia did not constitute political treason but instead consisted of a divinely sanctioned society of ascetics and priests who were restoring their church and disseminating Severan doctrines within the frontier zone. In such ways, the Life situates John of Tella in a position of mutual antagonism with Ephrem of Antioch in ways that posited a breach between upright "orthodox" behavior and participation in the Roman imperial regime. While John's own writings highlight the primary concerns of his ministry within the frontier zone and do not present the idealized vision of his ascetic network that appears in the works of sympathetic authors, the Life written by Elias, as well as that of John of Ephesus, reflect how his sympathizers interpreted the significance of his life and activities in the years following his death. For them, the clerical hierarchy and ascetic network that John had established constituted a spiritual politeia, a society of priests and monks that provided an alternative to potentially idolatrous participation in the empires of Rome and Persia.

\section{The Creation and Destruction of John's Politeia}

During the 520s, the exiled bishop John, along with numerous ascetic and clerical companions, had retired to the countryside of the frontier zone to appoint priests for nearby communities. Sympathetic contemporaries, such as an anonymous author of an ecclesiastical chronicle, employed the Greek loan word politeia (Syr: r. a (a) to conceptualize John's network of monks and priests as a corporate society for which John and his colleague Thomas of Dara served as "heads":

Indeed, it was a politeia of distinguished priests and believers, and it was a tranquil brotherhood that was with them. They were harmonious in their love, and they abounded with love of each other. They were beloved and welcomed among everyone. Nothing was lacking, for the venerable heads of the body consisting of all the limbs of the body, the holy John of Tella, an ascetic and fasting man, [and Thomas of Dara] came with them. ${ }^{12}$

12 Historia ecclesiastica Zachariae rhetori vulgo adscripta Vol. 2, 8.5, ed. E. W. Brooks, CSCO III 5-6 (Paris: E Typographeo Reipublicae, 191921), 81-2. Note that The Syrian Chronicle Known as that of Zachariah of Mitylene, tr. F. J. Hamilton and E. W. Brooks (London: Methuen \& CO., 1899), 211 translates politeia as "commonwealth." John probably had begun to ordain priests in the early 520 s with the result that a comprehensive network of priests had emerged by 530. Menze, Justinian, 175-86. 


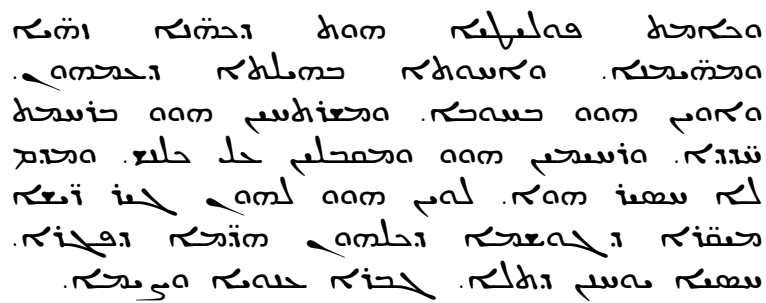

As shown in the quotation above, the term politeia, which encapsulated notions such as "commonwealth," "constitution," or "way of life," was used by the chronicle's author to describe the perceived community of shared values and practices that John had created. The association of John's community with the flexible concept of politeia seems to have persisted among his sympathizers after his death. According to John of Ephesus, the "politeia of the faithful faction" was in dire need of priests because John could no longer ordain them. ${ }^{13}$

The term politeia had numerous and overlapping meanings in Christian literature, both past and contemporary, and its varied connotations raised diverse interpretive possibilities for how the "politeia of the faithful faction" that John and his colleagues had established could be conceived. It was a word firmly grounded in the Greek classical tradition, and it had always been linked to scenarios of community formation and the behaviors that facilitated it. Philosophers such as Plato, Aristotle, and their successors had used it to formulate their theories of the constitutions of the Greek citystate. ${ }^{14}$ After Roman expansion had integrated the Mediterranean coastline into a single imperial system, dissenting groups often cited the term to describe how the customs and habits of their communities were both different and superior to those that Roman imperial oppression was endeavoring to foist upon them. The Jewish writer Josephus had celebrated the politeia established by Moses for the Jews as conducive to the formation of an exemplary community. ${ }^{15}$ In response to Greek and Roman detractors who criticized

${ }^{13}$ John of Ephesus, Lives of the Eastern Saints 49 (Life of James), PO 18, 490 [692].

14 Plato, Respublica, ed. S. R. Slings (Oxford: Clarendon, 2003), 544a-d describes the four basic forms of politeia as the Cretan or Lakonian, oligarchy, democracy, and tyranny. Aristotle, Politica, ed. W. D. Ross (Oxford: Clarendon, 1957), 1289a and 1292a establishes a politeia as a civic order maintained by laws and magistrates.

${ }^{15}$ Josephus, Ap., Flavii Josephi opera, Vol. 4, ed. Benedict Niese (Berlin: Teubner, 1890), 2.145-89 (the term politeia is cited in 188) and AJ, Flavii 
the Jewish way of life, Josephus claimed that Greek and Roman philosophers and lawmakers had in fact crudely imitated the laws and customs that Moses had invented. ${ }^{16}$ Likewise, early Christian authors habitually asserted that the virtues of their politeia were vastly superior to those of Greeks, Romans, or Jews, and in the same vein, the members of various philosophical schools, including Christian ones, had argued that the intellectual views, daily habits, or general ways of life that characterized their politeia were better than those of their rivals. ${ }^{17}$ After the reign of Constantine and his legitimation of Christianity, the term was increasingly assumed by monastic or ascetic communities to delineate how their elevated and rigorous way of life distinguished them from other Christians who did not share their ascetic regimens. ${ }^{18}$ Preachers intent on reforming the daily habits and attitudes of their congregations also cited it frequently in their efforts to prompt their audiences to cultivate a Christian way of life. ${ }^{19}$ In this sense, the term was also often

Josephi opera, Vol. 1, ed. Benedict Niese (Berlin: Teubner, 1887) 3.212-86 (politeia is cited in 212).

${ }^{16}$ Josephus, Ap., 2.280-2.

${ }^{17}$ Eph 2:12 describes Christians as "alienated" from the politeia of Israel. Tatian, Oratio ad Graecos, ed. Miroslav Marcovich, Patristische Texte und Studien, Vol. 43 (Berlin: de Gruyter, 1995) pits the politeia of Christians against those of Greeks and Romans. See especially 4.1-2 and 28.1. Like Josephus, Tatian, 34-42 argued that the politeia of Jews and Christians predated that of the Greeks. Similarly, Justin Martyr distinguished between a Christian politeia and that of the Romans in Apologia maior 4.2. See Justini Martyris apologiae pro Christianis, ed. Miroslav Marcovich, Patristische Texte und Studien, Vol. 38 (Berlin: de Gruyter, 1994). Also, Eusebius, HE 2.1.1, 4.7.14, 4.23.2, and 7.32.30, ed. Eduard Schwartz and Theodor Mommsen in Die Kirchengeschichte, GCS 6.1-2 (Berlin: Akademie Verlag, 1999).

18 The Historia Lausiaca of Palladius, for instance, focuses on the politeia of ascetics in Egypt. See The Lausiac History of Palladius, Vol. 2, ed. Cuthbert Butler (Cambridge University Press, 1898-1904), Proem, 9-10 and 33, 96. Likewise the term occurs countless times in Theodoret's Historia religiosa in reference to the ascetic way of life, and in his prologue he frames his efforts to describe the politeia of such ascetics. Theodoret, $H R$ Prol. 2.9, 9.2, and 10.2 in Histoire des moines de Syrie, Vol. 1, ed. Pierre Canivet et Alice Leroy-Molinghen, SC 234 (Paris: Cerf, 1977). Also, Eusebius, de mart. Palaest. 11.2, ed. Eduard Schwartz and Theodor Mommsen in Die Kirchengeschichte, GCS 6.2 (Berlin: Akademie Verlag, 1999). For differences between philosophical outlooks, namely those of "Hellenes" and Christians, see Eusebius' citation of Porphyry in HE 6.19.7.

${ }^{19}$ John Chrysostom, In Matt. 1.4 (PG 57, c. 18) expressed his desire to have his congregation assume the politeia of monks or the early church 
used to describe an individual's disposition or character, but even then it framed this individual, however unique, as included within a categorical group defined by the possession of certain common characteristics. For instance, to describe the politeia of individual Christians or ascetics was to narrate the qualities that framed them, and others like them, as Christians or ascetics. It is for this reason that when Eusebius described Jesus Christ "during the times of his incarnate politeia," he was narrating Jesus' life as a human who, like all other humans, had an incarnate politeia and human characteristics despite possessing unique individual traits. ${ }^{20}$

In this sense, the term politeia had traditionally been invoked to describe the elevated habits of a community and to locate differences between such a perceived community and "others" who allegedly conducted themselves in ethically inferiors ways. Originally used to distinguish the civilized inhabitants of Greek city-states from outsiders, Jewish and Christian authors had cited it to assert the supremacy of their community's habits over those of the Roman empire at large and eventually over other Christians who did not practice a monastic or ascetic lifestyle. As those sympathetic to John's activities assumed this term, it encapsulated all these connotations, and it thereby framed John's network as a community of "orthodox" ascetics operating beyond the vicissitudes of alternative politeiai, whether those of perceived heretics, pagans, Christians unaccustomed to rigorous asceticism, or the Roman and Persian imperial systems. It is therefore significant that while the use of this term to describe an ascetic community had been common among Christian writers, politeia was also the Greek translation of the Latin respublica and was a term employed in reference to the Roman and Persian empires. ${ }^{21}$ The politeia of John and his associates could be

fathers, and in In Jo. 28.2 (PG 59, c. 264) he distinguished the upright politeia of Christians from that which characterized the practitioners of pagan "Hellenism." Gregory of Nazianzus, Or. 41.8 (PG 36, c. 440) describes a politeia of those who profess the Holy Spirit.

${ }^{20}$ Eusebius, HE 1.4.1. See a similar usage in Historia ecclesiastica Zachariae rhetori vulgo adscripta Vol. 1, 1.1, 2. It describes the base "earthly character" that afflicted all humans.

${ }^{21}$ In his Ecclesiastical History, John of Ephesus routinely refers to the Roman empire as the politeia of the Romans or occasionally the politeia of Christians to distinguish it from the Persian empire. See Iobannis Ephesini historiae ecclesiasticae pars tertia, ed. E. W. Brooks, CSCO 105, Scriptores Syri 54 (Series 3, Vol. 3) (Louvain: Imprimerie Orientaliste, 1952), 73, 126-7, $153,215,271,274,276,278,285,291,306$, and 319. It is also used this way in a letter of Severus cited at length in Historia ecclesiastica Zachariae rhetori vulgo adscripta Vol. 2, 9.17, 131. 
construed not merely as a group of people sharing a doctrinal outlook and ascetic behaviors but as an alternative to idolatrous politeiai, and this spiritual politeia was responsible for organizing villagers into an "orthodox" church.

The network of ascetics and priests that sympathetic authors would classify as a politeia in their writings is in certain ways elucidated by John's own writings, Canons and Questions and Answers. Although they do not explicitly use the term politeia, his compositions outlined the ways by which his priestly candidates were to maintain modes of behavior that differentiated them from both heretics and the members of village congregations that they were to oversee. ${ }^{22}$ They therefore defined the priestly hierarchy and ascetic network that sympathetic authors would conceptualize as a politeia. The foremost aims of Canons and Questions and Answers were to ensure that their readers persisted to condemn all heresies defined as such by Severus of Antioch and Philoxenos of Mabbug and to avoid contact with those who supported the Council of Chalcedon, the tome of Leo, or the views of Julian of Halicarnassus. ${ }^{23}$ The texts contain specific prohibitions against eating and exchanging blessings with heretics, and they regulated how greetings and burials among both faithful priests and heretics were to be conducted. ${ }^{24}$

22 Scholars generally believe that John of Tella and John bar Qursus were the same individual. If so, under either name John wrote various letters and didactic texts. Canons and Questions and Answers, of specific relevance here, are published with translations by Arthur Vööbus, The Synodicon in the West Syrian Tradition, CSCO 367-8, Scriptores Syri 161-2 (Louvain: Secrétariat du CorpusSCO, 1975), 145-56 (142-51) and 211-21 (197-205). These treatises deal chiefly with the daily and routine issues of officiating over the village congregations with which John was concerned during his ministry on the frontier. These texts harmonize with John's two biographies, written by Elias and John of Ephesus, to present a portrait of John's frontier ministry, and they highlight the daily hardships that John faced in ensuring righteous behavior among his priests and laity. See Volker Menze, "Priests," pars. 6-10, 15-7 and "The Regula ad Diaconos: John of Tella, his Eucharistic Ecclesiology, and the Establishment of an Ecclesiastical Hierarchy in Exile," (OrChr 90 [2006]), 69-90 for thorough treatments of the problems that John's treatises sought to address. Refer to Menze, "The Regula ad Diaconos," 49-54 for the complex details concerning John's extant literary corpus and 55-60 for an edition and translation of his Regula ad Diaconos. An edition and translation of John's letter stating his faith is forthcoming in Kutlu Akalin and Volker Menze, John of Tella's Statement of Faith, TeCLA. Piscataway, NJ: Gorgias Press.

23 Synodicon 147, Canon 1.

24 Synodicon 147 and 215-7, Canon 2 and Answers 23, 25-8. 
These texts also prescribed strict modes of behavior that were to distinguish ascetic priests from the typical village congregation that they administered. Such prescriptions included restrictions on diet, drink, dress, contact with women, usurious practices, and physical deportment. ${ }^{25}$ Finally, it should be stressed that John's works indicate that he and his followers had developed ways to collect and redistribute wealth. John's Canons noted that many priests offered gifts to both their local church and their villagers upon their ordination, and he sought to regulate such donations in order to ensure that such conduct did not lapse into outright simony. ${ }^{26}$ At the same time, he mandated that such gifts, as well as the tithes that priests collected from villagers, should be invested in the maintenance of the church and hospitality toward strangers, the poor, orphans, and widows. ${ }^{27}$ In short, John's writings outlined a social system for collecting and redistributing wealth among "orthodox" villagers, and as will be highlighted in subsequent sections, Elias claimed that John's ability to "collect gold" was a matter of concern for Persian authorities.

Amid John's efforts to create a network of priests and monks characterized by a common mode of behavior and to establish a clerical hierarchy, Severus of Antioch, the deposed antiChalcedonian bishop of Antioch, sent letters to John and his associates. According to the Syriac translations of these letters, he praised their politeia and compared it to that of the Old Testament figure Elijah. ${ }^{28}$ If the Syriac translation reflects Severus' use of politeia in Greek, this analogy had manifold connotations for John's activity at the time. After escaping from the hands of idolaters by hiding in the wilderness, Elijah had been told by God that the seven thousand Israelites who had kept his covenant would be spared, and Severus' references to the Old Testament figure of Elijah suggested that John had effectively assembled a community

25 Synodicon 149-51, 153, 155, Canons 9-11, 15, and 26.

26 Synodicon 152-3, Canon 14.

27 Synodicon 151-2, Canons 11-12.

28 Severus of Antioch, The Sixth Book of the Select Letters of Severus, Patriarch of Antioch 5.14, ed. and tr. by E. W. Brooks (London: Williams \& Norgate, 1904), 389-90. 5.14, addressed to John, Philoxenos, and Thomas at Marde, is the focus here. Also relevant is 5.15, written to Sergius of Cyrrhus and Marion of Sura, which endorses the ordination of priests (402-4). For discussion of the seventh-century translator Athanasius, who was responsible for the Syriac version of the sixth book of letters, see the introduction of Brooks in The Sixth Book of the Select Letters of Severus, Patriarch of Antioch, ix-xi. 
of ascetics and priests characterized by an elevated and spiritual lifestyle. ${ }^{29}$ Yet, in addition to maintaining an ascetic regimen, they, like Elijah, were effectively maintaining a society of pious "Israelites" in the face of idolatrous forces. Severus' use of the term politeia thereby indexed the diverse meanings that the world encapsulated, and it cast John's network as an ascetic society that also resisted the current heretical inclinations of the Roman empire. While constituting an alternative to the temptations of the "world," it also could be the site of resistance to the idolatry of empires.

Although they otherwise do not develop what the concept of politeia signified for John's activity, it is significant that Syriac translations of Severus' letters and homilies in general cite the term politeia in ways that exhibit its numerous and overlapping potential meanings. If it is accepted that the Syriac translation of the term reflects Severus' usages in Greek, such letters and homilies reflect the complexity with which the term politeia had been endowed during the lifetime of John of Tella. For instance, Severus' letter to Simeon, a cleric and the archimandrite of the monastery of Teleda, exhorted him to receive into the "orthodox" fold those who had previously been opposed to it and criticized his recent reluctance to do so. ${ }^{30}$ In a reference to a passage from Proverbs, Severus' letter argued that according to this "priestly text," the cultivation of patience enabled kings or emperors to "prosper" or be "consecrated,"

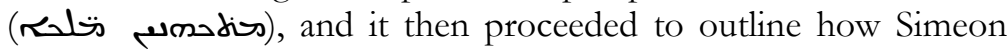
should exercise similar forms of patience. ${ }^{31}$ Accordingly, if the Syriac translation accurately reflects the premises of Severus' Greek, the letter was suggesting a comparison between Simeon's duties as archimandrite and the conduct of an Old Testament king. Severus' letter then told Simeon, an ordained cleric himself, that "it befits your politeia" to receive with patience and humility wayward monks into a community of the faithful. ${ }^{32}$ Such use of the term

${ }^{29}$ Severus of Antioch, The Sixth Book of the Select Letters of Severus, Patriarch of Antioch 5.14, 389-90. In this specific passage, Severus is citing the description of Elijah's activities presented in 1 Kings 19:13-4. By referring to Elijah's flight onto the hill of Horeb explicitly, Severus was intent on comparing how both Elijah and John's companions were responsible for consolidating the faithful in a time of idolatrous persecution.

${ }^{30}$ Severus of Antioch, The Sixth Book of the Select Letters of Severus, Patriarch of Antioch 5.9, 365.

31 Severus of Antioch, The Sixth Book of the Select Letters of Severus, Patriarch of Antioch 5.9, 365. Citing Pr 25:15.

32 Severus of Antioch, The Sixth Book of the Select Letters of Severus, Patriarch of Antioch 5.9, 365. 
politeia stressed that Simeon, as archimandrite, was supposed to assume the patience of the Old Testament kings of Israel, but it also emphasized Simeon's leadership over a community with a shared set of ascetic behaviors and doctrinal outlook. To have a politeia was to be a member of a community and to assume the character and behavior of that community. Simeon belonged to a politeia of patient and forgiving monks, and as its abbot, he was to act as a "priestly emperor" who upheld its righteous ways.

Likewise, another letter of Severus used the term politeia to describe the community and laws that Moses had established for Jews. In this letter, Moses' politeia served as a point of contrast with that of the Gospel, which had supplanted it through the intercession of Christ. ${ }^{33}$ In a homily that he composed as bishop of Antioch, Severus described how demons exploited the laws and politeia of "tyrants and governors" in order to make such imperial figures set upon martyrs like wild beasts. ${ }^{34}$ As described above, Jewish and Christian authors had in certain instances pitted their politeiai against those of worldly empires that could engage in repressive activity toward them, and Severus' multi-faceted employment of the term highlights the various interwoven significances with which sympathizers could have endowed John's ministry. His was a politeia of ascetic "orthodox" which contravened the mandates of the worldly, idolatrous politeia of an empire, and the activities of its spiritual leaders, its "priestly emperors" modeled on the divinely anointed kings of the Old Testament, could posit challenges to the tenets of earthly ones.

Because of the polyvalent connotations of the term politeia, John's clerical and ascetic network could be construed as an alternative society and political entity that challenged the sovereignty of Roman and Persian magistrates and not a mere philosophical concept or a group of ascetic practitioners. ${ }^{35}$ Indeed, the word encompassed many meanings and operated in many semantic contexts, and John's supporters could thereby exploit its endless ambiguity to describe a network of ascetic and priestly communities binding

${ }^{33}$ Severus of Antioch, The Sixth Book of the Select Letters of Severus, Patriarch of Antioch 10.1, 486-8.

34 Severus of Antioch, Homélie 86, in Homiliae cathedrales, ed. Maurice Brière, PO 23 (Paris: Firmin-Didot, 1932), 44-5 [312-3].

35 For a similar postulation of a "commonwealth" of the antiChalcedonian faithful, especially in reference to the activity of Simeon of Beth-Arsham, see Garth Fowden, Empire to Commonwealth: Consequences of Monotheism in Late Antiquity (Princeton: Princeton University Press, 1993), 129-30. 
together the frontier territories of Rome and Persia. Yet, the ambiguity encapsulated in the word politeia made John more vulnerable to the attacks of his enemies, who could claim that he was not merely undergoing an ascetic retreat within the frontier, but that he was also engaging in politically treasonous activity by persuading locals to value the authority of his politeia over that of the Roman and Persian imperial administrations. This vulnerability could only have been exacerbated by the fact that the Roman imperial administration supported Chalcedonian bishops whereas the Persian monarchy at this time recognized the Church of the East, which John's missionary efforts also targeted, to be the only legitimate Christian sect within its realm..$^{36} \mathrm{~A}$ frontier politeia of Severan priests and monks trying to edify their enfeebled church could easily transgress the interests of the two mighty empires.

\section{The Frontier Politeia ANd Cultural Interaction}

In his endorsement of John's ordinations, Severus, the exiled bishop of Antioch, had exhorted John and his colleagues to gather followers "from those who are near you and far from you throughout the lands," and John's politeia took on connotations of cultural interaction. ${ }^{37}$ According to both his biographers, the ministry of John and his companions was extensive, and would-be clerics came from all regions of the eastern empire and even from Persia and Armenia. ${ }^{38}$ Many of these Persians became bishops and returned to Persian territory in order to administer congregations. ${ }^{39}$ The members of John's politeia thereby consisted of various groups of "distinguished priests and believers" dispersed throughout the fron-

${ }^{36}$ For the attempt of John and his colleagues to guide Persians from the "error" and "wicked doctrine" of Nestorius, "the servant of humanity," see Vita Iohannis Episcopi Tellae 36 and 60-1. For Persian recognition of the Church of the East, see Wilhelm Baum and Dietmar W. Winkler, The Church of the East: A Concise History (London: RoutledgeCurson, 2003), 14-7.

37 Severus of Antioch, The Sixth Book of the Select Letters of Severus, Patriarch of Antioch 5.14, 393.

38 Described by Vita Iohannis Episcopi Tellae 58-62; John of Ephesus, Lives of the Eastern Saints 24 (Life of John of Thella), 317 [519]. John of Ephesus also claims that visitors came from Arzanene, which was a Mesopotamian district controlled by the Persians. Perhaps Elias is referring to men from this region specifically when he mentions the "Persian" episcopal candidates.

39 Vita Iohannis Episcopi Tellae 58-62. 
tier. ${ }^{40}$ The writings of John of Tella himself also reflect such a trend. In addition to reinforcing distinctions between the "orthodox" and "heretics" and asserting the authority of priests over common laypersons, John's Questions and Answers addressed the issues that arose because of the networking that occurred among clerics and ascetics from both Roman and Persian regions. John, for instance, expressed concern that frequent contact among people on both sides of the frontier would make it easy for altars and other objects that members of the Church of the East used in their rites to be unwittingly incorporated into the sacred rituals of the "orthodox." 41 John also mandated that when Christians from Roman and Persian territory met in friendship, Romans should not give their Persian counterparts a piece of the Eucharist in order to solidify social bonds. ${ }^{42}$ Not content with integrating those who inhabited the Persian frontier into his ascetic network, as Elias claimed, John also sought to convert Arabs and nomads. He sent letters to the phylarch al-Mundir, and his enemies' allegation that he ate camel suggests that he interacted with nomads personally. ${ }^{43}$ According to John of Ephesus, John rigorously maintained an archive of documents that recorded the various faithful priests whom he had appointed through numerous lands, just as the Persian Simeon of Beth-Arsham had done before him. ${ }^{44}$ By the mid-530s, John had even relocated to Mt. Singara in Persian territory, where he was eventually captured by Persian military forces.

John's ministry extended to both sides of the frontier, and his ordinations thereby enabled the anti-Chalcedonians of both Roman

${ }^{40}$ Historia ecclesiastica Zachariae rhetori vulgo adscripta Vol. 2, 8.5 describes at length the mass exodus of monks driven from monasteries into the remote regions of the East. Severus of Antioch, in The Sixth Book of the Select Letters of Severus, Patriarch of Antioch 5.15 addressed to Sergius of Cyrrhus, had exhorted John and his companions to ordain priests, and John accordingly began to attract monks, clerics, and ordination prospects.

41 Synodicon 220-1, Answers 43-7.

42 Synodicon 219-220, Answer 42.

43 See Irfan Shahîd, Byzantium and the Arabs in the Sixth Century, Vol. 2 (Washington: Dumbarton Oaks, 1995), 710 for missionary activity that can possibly be linked to John of Tella. See Vita Iohannis Episcopi Tellae 623 for John's letters to the camp of al-Mundir and 92 for John's alleged camel diet. John's letters to al-Mundir were intended to contest the alleged spread of Julianist doctrines among Arabs.

${ }^{44}$ John of Ephesus, Lives of the Eastern Saints 24 (The Life of John of Thella), 518-9 [316-7] and 522 [320] and 10 (Life of Simeon the Bishop), ed. E. W. Brooks, PO 17, 155-6. 
and Persian controlled Mesopotamia to be integrated conceptually into a single united church. In fact, John of Ephesus interpreted John's activity as the precursor to that of Jacob Baradeus (Bard'āyā), who appointed priests on both sides of the frontier, and his own account of John's activity resembles his description of himself as a leader of deacons originating from Syria, Armenia, and Persia. ${ }^{45}$ That is, John of Ephesus cast himself as perpetuating the culturally eclectic ministry of John of Tella. Both biographers of John thereby perceived that the membership of "believers" within John's politeia was determined by faith and ascetic behavior, not ethnicity, culture, or native region, and it had the potential to transcend the authority of the imperial institutions that sanctioned persecution and endorsed religious impiety. ${ }^{46}$ The members of such a politeia, bound by their common faith, could claim not to differentiate between territory administered by Persians and Romans. This aspect of John's ministry, however, encouraged his opponents to claim that he was revolting against the emperor and that he refused to acknowledge each empire's authority and definition of civic

45 John of Ephesus, Lives of the Eastern Saints 49 (Life of James), 490 (692) for Jacob as continuing John's work. For John's account of his activity in converting pagans in Asia Minor, during which time he was supported by numerous Syrian priests, in addition to others who belonged to a genos beyond the eastern frontier, such as those to be found in Persia and Armenia, see John of Ephesus, Lives of the Eastern Saints 43 (Lives of Four Deacons), PO 18, 456-7 [658-9].

46 According to Sebastian Brock, "Christians in the Sasanian Empire: A Case of Divided Loyalties," in Religion and National Identity, Studies in Church History 18 (Oxford: Blackwell, 1982), 13 and 18, it was typical for Persian Christians not to divide their conceptual world between Roman and Persian but between "The People of God" and "those outside," or between the "true 'People of God' and 'heretics." Christians whose earthly loyalty was to the Roman emperor seem to have exercised a similar perception of the world. Also see Drijvers' comments, which suggest that the Greek, Iranian, and Semitic cultural strands that flourished in second century Edessa were experienced as an indistinguishable unity. Although his comments are focused on the city of Edessa during the lifetime of the philosopher Bardaisan, they show that the eastern frontier had enjoyed a tradition of cultural interaction that John's politeia could utilize. Han J. W. Drijvers, "Bardaisan von Edessa als Repräsentant des syrischen Synkretismus im 2. Jahrhundert n. Chr.," in Synkertismus im syrisch-persischen Kulturgebiet, ed. A. Dietrich (Göttingen: Symposion, 1971), 119. For comments on the frontier zone's ability to create a sense of common identity among Christians, "whether Roman, Iranian, or from somewhere in between," see Elizabeth Fowden, The Barbarian Plain: Saint Sergius between Rome and Iran (Berkeley: University of California, 1999), 58-9. 
identity. ${ }^{47}$ In fact, he had continued to ordain priests even though the emperor Justinian, at a disputation held in Constantinople in 532, commanded him not to do so, and his activity therefore exposed him to accusations of treason. ${ }^{48}$

For such reasons, Elias' Life is extremely preoccupied with dispelling any premise that John's activity was treasonous, even as it suggested that John's community undermined the imperial authority of both the Romans and the Persians. He therefore presented John's encounter with the Persian Marzban and his surrogates in ways that articulated that John and his companions had upheld the will of God amid the Roman emperor's current failure to do so. $\mathrm{He}$ also outlined the ways by which Persian authorities had misinterpreted John's ministry as some form of criminal activity. According to him, the Persian comes directly responsible for his capture classified him as an "evil man" who was "worthy of an evil death," and in his account both Roman detractors and Persian authorities are depicted as asserting that John had amassed a personal following of villagers and nomads by appointing priests over rural congregations. ${ }^{49}$ In addition, Elias claimed that the bishop Ephrem had per-

47 Vita Iohannis Episcopi Tellae 58. For this reason, Elias stated that John "despised the threats of monarchs" when he began his ministry of priestly appointments.

48 John's conduct at the disputation at Constantinople, which most likely occurred in 532, is recorded in Vita Iobannis Episcopi Tellae 59-60. John's migration to Singara is described in 60-1, although the name of the mountain is not actually given until 66. For information on the documents recording the proceedings, see Sebastian Brock, "The Conversations with the Syrian Orthodox under Justinian (532)" (OrChrP 47 [1981]), 88. An anonymous summary of the proceedings generated by anti-Chalcedonian partisans has been published by F. Nau, Textes Monophysites, PO 13 (Paris: Firmin-Didot, 1919), 192-6. An edition and translation of the acephalous doctrinal statement of John and his companions at Constantinople, as well as a translation of the summary given by the anti-Chalcedonians, has been presented by Sebastian Brock, "The Conversations with the Syrian Orthodox under Justinian (532)," 87-121. This anonymous summary and Vita Iohannis Episcopi Tellae 59 record how Justinian ordered John and his colleagues to stop performing ordinations. See Brock, "The Conversations," 115 for his analysis of Brook's edition of Vita Iobannis Episcopi Tellae 59 and his conclusion that Justinian prohibited John from ordaining more priests but allowed him to perform baptisms and to give the sacrament to his congregations. For recent examination of the disputation and the significance of the Libellus of Hormisdas in affecting its development, see Menze, Justinian, 58-67 and 94-105.

49 Vita Iohannis Episcopi Tellae 68. 
suaded the Persian Marzban of Nisibis to send out a joint force of Persian and Roman soldiers to raid John's community on the mountain of Singara by telling lies and offering bribes. ${ }^{50}$ Once John was captured and brought to Nisibis, the Marzban in Elias's account accused him of a series of crimes that were based, as Elias hinted, on Ephrem's presentation of John's activity. The first was that John had "crossed into our land without our permission," thereby entering "another politeia." 51 The second was that he was "collecting much gold from those who came" to him, thereby collecting and redistributing wealth among the local communities over which he had influence. ${ }^{52}$ The third was that he was "rebelling against Caesar and those who rule his land." 53 According to Elias, John's enemies had in such ways expanded initial charges of simony and illicit priestly ordinations into an accusation that he was staging a revolt apparently facilitated by his ability to collect wealth and to assemble a gang of followers, and they had stressed that John was openly defying the authority of both Roman and Persian imperial magistrates. Since Elias cast the Persian authorities as being less concerned with John's ecclesiastical infractions than his potentially disruptive influence over local communities in the frontier zone, he presented the Marzban's three accusations as reflecting his suspicion of the ability of John and his associates to acquire resources, attract followers, and administer local congregational communities within both Roman and Persian territory. Because of such interpretations of John's activity, as Elias claims, his benign religious ministry had been likened to rebellion.

However, according to Elias, when John heard the Marzban's allegations, he denied that his activities in Persia constituted disloyalty or unlawful conduct. In response to the Marzban's first accusation about his illegal entry into the Persian politeia, John stressed that the present peace enabled him to ignore the distinction be-

50 Vita Iohannis Episcopi Tellae 68 and 71-3. Elias claims that Ephrem told many lies (66) about John in order to persuade the Persians to abduct him, and the Persians, before they captured him, had a preconceived notion that he had committed treason.

51 Vita Iohannis Episcopi Tellae 71. The line reads:

> Ridid

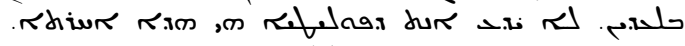

52 Vita Iohannis Episcopi Tellae 72. The line reads:

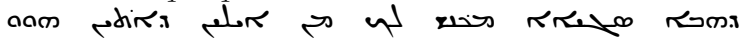

53 Vita Iohannis Episcopi Tellae 72-3. The line reads:

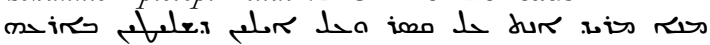


tween the "commonwealths" and between the inhabitants of Rome and Persia. He proclaimed:

Today, when there is this complete peace between these two empires, I do not know politeia from politeia, for the two emperors are brothers in love. If I am here, I think that I am among the Romans. If I am among the Romans, I think that I am here because of the peace. ${ }^{54}$

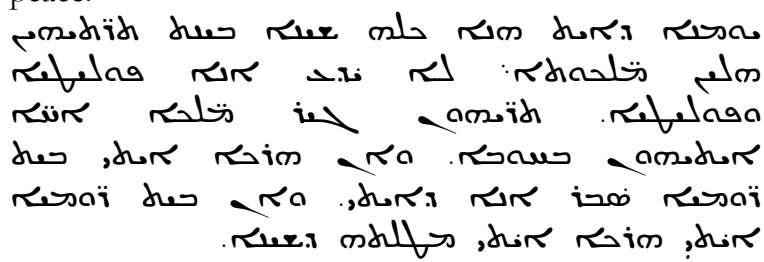

After making this statement, John then denied that he had collected any gold, and he assured his interrogator that he obeyed the Roman emperor in worldly affairs but could not be fully reconciled with him until he ruled "his kingdom according to God's will."55 So long as the emperor ruled without God's will, the Roman imperial administration had no authority over him. This sentiment was also articulated in the biography of John of Tella written by John of Ephesus, who claimed that John had professed to have rejected an earthly emperor for a heavenly one and explicitly compared his captivity in Antioch to the martyrdom of Ignatius in Rome. ${ }^{56}$

The purpose of John's responses, as the author of his Life presented them, was to assure the Marzban that he was not hostile to either the politeia of the Persians or that of the Romans; the rigid distinction between them had been made obsolete by the current peace between the Roman and Persian monarchs and by the holy community that John had created in the frontier zone during this period of calm. Similarly, John recognized the temporal authority of the emperor, but because the emperor refused to yield to divine authority, he and his companions had to create a community that actually did. According to the author, John's explanations satisfied the Persians; they decided that John was not in revolt against the

54 Vita Iohannis Episcopi Tellae 72.

55 Vita Iohannis Episcopi Tellae 73. Although John maintained that he was subject to the emperor, he also claimed that he prayed that he would rule his kingdom according to God's will. The clear implication was that John had to conduct his frontier ministry beyond the Roman empire's authority until the emperor and his administration changed how they governed their realm.

${ }^{56}$ John of Ephesus, Lives of the Eastern Saints 24 (Life of John of Thella), 318 [520], 320-1 [523-4]. 
Roman emperor, and they handed John over to Ephrem only in exchange for gold. ${ }^{57}$ Still, in Elias' account John never agreed to obey the Roman emperor when he acted against John's religious convictions, and the needs of his frontier Christian politeia therefore retained precedence over imperial mandates, whether Roman or Persian. In fact, such an interpretation also emerged in the biography of John written by John of Ephesus, who too presented John's ascetic and clerical network as adhering to the will of the heavenly emperor while resisting the idolatrous mandates of earthly ones.

Accordingly, in Elias' estimation, John's ability to persuade the Marzban of his innocence reaffirmed the authenticity of his politeia as a society transcending the political divide between Rome and Persia. John proclaimed his denial of a boundary between the two empires in the disputed city of Nisibis, and his alleged success in persuading the Marzban, a figure of authority whose primary function was to discern and defend the boundary of the Persian politeia, enabled the author to cast John as the legitimate leader of an authentic commonwealth. According to Elias's perspective, John had exposed the artificiality of the border located between Nisibis and Dara, which only existed through administrative logistics and the rigorous implementation of military force. His peaceful and divinely sanctioned politeia was authentic, but so long as they sustained idolatry, the Roman and Persian politeiai were the flawed figments of human artifice and embedded only within the material world, to be obeyed by servants of corporeal matter. For this reason, Elias conceived of them as contrived and fake empires "of men," not God. ${ }^{58}$ In the years following John's death, both Elias

${ }^{57}$ In "Christians in the Sasanian Empire," 14, Brock points out that Persian Christians had succeeded in recognizing both "Christ and a temporal Shah." Accordingly, John's statement that he recognized an "earthly emperor" would have sounded reasonable to Persians who by this period accepted Christians who belonged to the Church of the East as loyal subjects.

${ }^{58}$ This is argued by Vita Iobannis Episcopi Tellae 54-6 in its description of John's resistance to imperial authority during his brief tenure as active bishop of Tella. According to Elias, John's lay opponents, who wanted to acquiesce to the will of the emperor, were bound by "the corporeal"

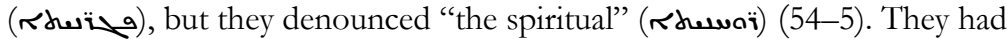
therefore argued that they could not resist the emperor's mandates. Elias elaborated further that such men were "serving corporeal pleasures" (هلer), and he claimed that John reproached them for gratifying men and not God (55-6). In fact, the author claims that John made a nearly identical statement to the emperor Justinian at the disputation which he held in Constantinople in 532 (59). The author's arguments 
and John of Ephesus produced their versions of John's life to emphasize that these empires and their contrived boundaries were not to be heeded by the truly faithful, who were to obey the heavenly emperor and not an earthly one when their mandates were contradictory. For such authors, John's politeia represented a community of ascetics and priests who had done exactly that, despite the hardships and tribulations that earthly empires had wrought.

\section{JOHN AND EPHREM: STRATEGIES OF AUTHORITY}

While framing John's ascetic network and clerical hierarchy as a politeia, both biographies of John of Tella portray him and his nemesis Ephrem as polar opposites. In addition to contrasting John's moral elevation with the degeneracy of Ephrem, both sources indicate that their careers were anchored in entirely different criteria of authority. John had been born into a family of notables who had educated him in Greek letters, and he had been an apprentice of the $d u x$ of Callinicum. Yet, he had eventually renounced a career within the Roman imperial administration, had become an ascetic, and had been compelled by anti-Chalcedonian priests to be the bishop of Tella. ${ }^{59}$ After his exile, he fled to the wilderness frontiers of Roman Syria and Persia where he remained beyond the reach of Roman magistrates, except for his participation at the disputation which Justinian assembled in Constantinople in 532.60 During his extended exile, John challenged the arbitrary political boundaries dividing frontier communities which in many ways shared a common culture and language, namely Syriac. ${ }^{61}$ In

thereby located the Roman imperial mechanisms that sustained the Chalcedonian position within human artifice and the material realm, as opposed to the spiritual and divinely sanctioned underpinnings of John's politeia.

59 These statements summarize the sequence of events of Vita Iohannis Episcopi Tellae 39-57.

${ }^{60}$ Vita Iohannis Episcopi Tellae 57-74; John of Ephesus, Lives of the Eastern Saints 24 (Life of John of Thella), 313-8 [515-20]; Brock, "The Conversations, 87-121; F. Nau, Textes Monophysites, 192-6.

${ }^{61} \mathrm{~J}$. H. W. G. Liebeschuetz, The Decline and Fall of the Ancient City (Oxford: Oxford University Press, 2001), 259-60. See also W. H. C. Frend, The Rise of the Monophysite Movement: Chapters in the History of the Church in the Fifth and Sixth Centuries, 2nd ed. (Cambridge: Cambridge University Press, 1979), 320-1. These authors emphasize the increasing solidarity among the anti-Chalcedonians on both sides of the frontier. This is not to say that the culture of Mesopotamia was homogenous during this period; the previous interventions of Greeks, Romans, and Persians had influenced 
short, John had built his reputation by conducting his ministry beyond the hegemony of Roman and Persian imperial structures.

In Elias' account, John's resistance to imperial idolatry and his answers to the accusations of his Persian captor are presented as neither circumstantial nor isolated occurrences. While John of Ephesus framed the bishop as a second Ignatius, for Elias, he was cast in the likeness of Paul the "Apostle," and his imitation of Paul over the course of his entire life had made his resistance to imperial idolatry inevitable. According to Elias, John's reading of Paul's letters or accounts about Paul's ministry had determined his course of action during every significant turning point of his life: his ascetic conversion, his efforts to flee the episcopate, his conduct as bishop, and his frontier ministry. ${ }^{62}$ Not only that, Elias' account portrayed John as not only modeling his personal behaviors on those of Paul but as quoting his epistles so often that the two figures become increasingly indistinct. Elias' John was virtually a reanimated Paul who breathed new life into Paul's own words during his frontier ministry, and when Elias claims to repeat the injunctions that John had spoken to him or others, these quotations mostly consist of citations of Paul's letters. ${ }^{63}$ According to Elias,

the cultural practices of the region, and various communities certainly possessed their own local customs. Nonetheless, the Syriac language was dominant in both western and eastern Mesopotamia, and this feature distinguished the culture of Mesopotamia from that of western Syria, where Greek was more widely used. Syriac was also widespread among the villages with which John and his followers were in contact. See Segal, "Mesopotamian Communities from Julian to the Rise of Islam" (PBA 41 [1955]), 109-10, 121-2, 130 and Sebastian Brock, "Greek and Syriac in Late Antique Syria," in Literacy and Power in the Ancient World, ed. Alan K. Bowman and Greg Woolf (Cambridge: Cambridge University Press, 1994), 152.

${ }_{62}$ Vita Iobannis Episcopi Tellae 42, 44, 51-2, 58, 63-4. By Paul's letters, I refer to all the letters of the New Testament that were generally attributed to Paul in antiquity. In 42, John's ascetic conversation is motivated by his reading of the account of the "blessed Thecla," Paul's notable female disciple. Elias typically has John pondering a slew of Paul's quotations in his own mind whenever he has to make a personal decision about his lifestyle and speaking them aloud to others when exercising his pastoral charge. The number of specific Pauline citations or paraphrases are too innumerable to recount or discuss in detail, but Brook's Latin Versio of Elias' account diligently records the biblical verses used for the pages cited here.

${ }^{63}$ Vita Iohannis Episcopi Tellae 63-4. See the previous footnote for Elias' treatment of John's verbal citation of Paul. 
John had so thoroughly imitated Paul and his detachment from the corrupting affairs of the "world" that he had even become incapable of "rendering unto Caesar the things of Caesar's." ${ }^{4}$ It was no surprise that John had abandoned his position in the imperial administration to become an ascetic and an obstacle to its idolatrous forces.

By contrast, near contemporary sources indicate that Ephrem's career and authority were based on his involvement within the Roman imperial system. ${ }^{65}$ Born in Amida, he had received a Greek education, had risen through the ranks of the Roman administration, and had served in Antioch as comes Orientis, a powerful office that aided him in his appointment as bishop of Antioch and allowed him to exploit his previous political connections to destroy dissident monasteries with soldiers. ${ }^{66}$ Instead of being the pastor of peasants and nomads on both sides of the frontier, he aligned himself with Roman imperial authority, its official religious doctrine, and the clerical hierarchy that it sustained in Constantinople and Antioch. Accordingly, while John's career and his notion of a

${ }^{64}$ Vita Iohannis Episcopi Tellae 42. John makes this claim to his mother.

65 Ephrem's surviving works were written in Greek. For details and bibliography about Ephrem's fragmentary works, see Patrick Gray, The Defense of Chalcedon in the East (451-553) (Leiden: Brill, 1979), 141-54. Ephrem's surviving fragments are extremely theological in orientation and unfortunately reveal little about how he interacted socially with his congregation or with his enemies, such as John of Tella.

${ }^{66}$ See Susan Ashbrook Harvey, Asceticism and Society in Crisis (Berkeley: University of California Press, 1990), 62 for further details and bibliography on Ephrem. Historia ecclesiastica Zachariae rhetori vulgo adscripta Vol. 2, 8.4, 76 reports that Ephrem was comes Orientis when he was appointed bishop. Ephrem's embodiment of both imperial and ecclesiastical power was exemplified by his ability to negotiate with Persian authorities, abduct John, and try him in an ecclesiastical court without interference. During Justinian's reign, the Chalcedonian church had developed its own court system that functioned independently of other civil courts. See Caroline Humfress, "Law and Legal Practice in the Age of Justinian," in The Cambridge Companion to the Age of Justinian, ed. Michael Maas (Cambridge: Cambridge University Press 2005), 178-9 for the development of ecclesiastical courts. Humfress stresses that the emperor Justinian upheld the decisions of church councils as though they "emanated from the res publica itself" and that the defensores ecclesiae or ekdikoi could intervene in both civil and criminal cases to protect the church's interests. Accordingly, although Ephrem prosecuted John within the ecclesiastical court system with his own scholastici and ekdikoi, he embodied the prerogatives of the Roman politeia. For the hostility of the scholasticus Rufinus, see 79-85. For the presence of ekdikoi at John's trial in Antioch, refer to 87. 
Christian politeia highlighted the commonality of people on both sides of the frontier, Ephrem's career and outlook demanded conformity to the old order. His destruction of John's community can therefore be seen as an attempt to keep eastern Syria within the sphere of Chalcedonian religion, but it also had the effect of ensuring the regional primacy of Antioch and the prerogatives of a Roman imperial administration anchored within urban communities. Equally as significant, Elias hinted that if John's divinely authenticated politeia was characterized by peace on the frontier, then the joint assault that the Romans and Persians launched against it at Ephrem's behest had violently reaffirmed the artificial boundary between Rome and Persia. In Elias's narrative, such violence exemplified the activity of humanly contrived imperial structures mired within a corrupt sensory world. By serving the emperor during a period of idolatry, Ephrem served humanity and a corporeal politeia, not God and a spiritual one.

Yet, Elias was not alone in his deployment of rhetorical strategies; if his account is accurate, John's opponents frequently resorted to similar tactics. By integrating the ascetic communities and villages of the frontier into an inclusive network that his supporters conceptualized as a politeia, John had raised the possibility that religious and cultural authority could be centered on the frontier of Rome and Persia. Nonetheless, the very nature of his activity made him vulnerable to the attacks of his opponents in Roman Syria, who stressed his marginality and isolation from more traditional centers of political and cultural authority, such as Antioch and Constantinople. The author was undoubtedly aware of this. He carefully recorded how John's enemies accused him of rebelling against Caesar. He noted how in his youth John coaxed his paidagogos to neglect Greek literature in favor of learning the psalms in Syriac, a language more suitable for his future ministry on the frontier than for participation in the Roman imperial administration or contact with other churches in the eastern Roman empire. ${ }^{67}$ In fact,

${ }^{67}$ See Vita Iohannis Episcopi Tellae 92 for the accusation of camel and donkey consumption. For John's education in the Syriac psalms, see 43 and Sebastian Brock, "Greek and Syriac in Late Antique Syria," 156. It is important to emphasize, however, that Syriac was not merely spoken in the countryside and among peasants, but it certainly penetrated Syrian cities and found use among aristocrats. John's usage of the Syriac language did not limit his pastoral intentions to villagers. See David G. K. Taylor, "Bilingualism and Diglossia in Late Antique Syria and Mesopotamia," in Bilingualism in Ancient Society: Language Contact and the Written Text, ed J. N. Adams, Mark Janse, and Simon Swain (Oxford: Oxford University Press, 
the author believed that Ephrem exploited John's immersion within local frontier culture in order to liken him to the nomads with whom he consorted. The accusations of camel and donkey eating, the trademarks of a pastoral and un-civilized lifestyle, were certainly meant to have his effect. ${ }^{68}$ But in addition, John's enemies treated his ascetic retreat as evidence of his savage behavior, his evil character, and his lust for rebellion. ${ }^{69} \mathrm{He}$ wore a hair shirt and a long beard not because of his rigorous asceticism but to deceive people into obeying his authority and to conceal his rebellious in-

2002), 304-6, 330-1. The recent work of Adam Becker, Fear of God and the Beginning of Christian Wisdom: The School of Nisibis and Christian Scholastic Culture in Late Antique Mesopotamia (Philadelphia: University of Pennsylvania Press, 2006), 35-6, 38 emphasizes the significance of John's conversion to Christian asceticism and his cultivation of the Syriac psalms to be his "rejection of an elite Greek form of learning" and his re-orientation towards Scripture and Christian works. The recent study of Fergus Millar, The Greek Roman Empire: Power and Belief under Theodosius II (408-450) (Berkeley: University of California Press, 2006), 93-107 stresses that Greek was the lingua franca that facilitated communication among the inhabitants of all regions of the Greek east, and it was therefore the dominant language of church councils and the language that magistrates used to communicate with local populations. Although Syriac was a significant language within Syrian regions, it was not familiar to magistrates and churchmen from other areas of the eastern Roman empire and not nearly as serviceable at places such as Constantinople, as argued in 114-6. The author therefore certainly emphasizes John's interest in Syriac in order to stress his orientation towards the frontier of Rome and Persia, not towards Antioch and Constantinople. At the same time, this is not to argue that Syriac, as opposed to Greek, had become an exclusive expression of Syrian nationalism or identity. In fact, many anti-Chalcedonians, including Severus of Antioch, were Greek speakers, and the Chalcedonian faction certainly included individuals fluent in Syriac. However, John's ministry, which relied heavily on Syriac to communicate with villagers on both sides of the frontier, raised the possibility that Syriac could perhaps displace or decenter Greek and Latin as languages of power and authority among the anti-Chalcedonians of the region.

${ }^{68}$ For an exploration of "pastoralism" as being at "the distal end of the spectrum from agriculture" and the association between "flesh eating" and pastoralism in classical sources, see Brent Shaw, "Eaters of Flesh, Drinkers of Milk': The Ancient Mediterranean Ideology of the Pastoral Nomad," (Ancient Society 13-4 [1982/3]), 12-9, 29-30 (quotation on 18).

${ }^{69}$ Vita Iohannis Episcopi Tellae 68. The comes that captured John claimed that he would not have lived remotely in desert mountains and among lions and boars if he had not been evil and rebellious. 
tentions. ${ }^{70}$ If Elias' representation is accurate, by transforming John's ascetic qualities into emblems of savagery and treachery, John's enemies had emphasized his activity on the margins of civilization in order to liken him to the exemplification of social and political subversion: the bandit.

Neither the Roman nor the Persian imperial systems entirely integrated the populations of the geographical landscapes that they claimed to govern. Imperial authorities therefore reckoned such groups of people as bandits, as virtual non-persons who possessed no status because of their inability to be functioning members of an imperial system..$^{71}$ Similarly, John himself was no longer adequately integrated into the governing structures of either Rome or Persia. ${ }^{72}$ Although his enemies never accused him of violent acts of banditry, his isolation from the governing structures of Rome and Persia and his authority among the villages of the frontier exposed him to accusations of treason and savagery from the representatives of imperial regimes. Like a bandit, John had exerted tremendous charismatic authority within a frontier territory where imperial institutions had limited influence. Because of this, Elias' account emphasizes that representatives of imperial authority, such as Ephrem and the Persian Marzban, had conceptualized John as both a "disturber of the Church" and a savage agitator against imperial stability, and they negated this threat through force. ${ }^{73}$

According to roughly contemporary sources, when Ephrem abducted John to Antioch, he further displayed these perceived differences between his civilized status and John's savagery. John's

${ }^{70}$ Vita Iohannis Episcopi Tellae 77-8.

71 See the analysis of Brent Shaw, "Bandits in the Roman Empire," Past and Present 105 (1984), 21-2, 41-2. Bandits did not belong to the same category as other types of criminals because their actions occurred outside the authority of the empire's civil and criminal legal system and therefore effectively challenged the actual legitimacy of "state" institutions. Because of this, imperial representatives virtually rendered bandits as "nonpersons," as people who did not possess any defined status within the Roman imperial system or within that of a rival state, such as Persia. For a recent study that emphasizes bandits as a literary type, see Thomas Grünewald, Bandits in the Roman Empire: Myth and Reality (London: Routledge, 2004).

72 In fact, John's ascetic retreat on Mt. Singara was so remote that the Maryban's soldiers had to bribe a local Julianist ascetic to find it, and when they captured John, they had great difficulty navigating their way back to the road leading to Nisibis. Vita Iohannis Episcopi Tellae 67, 69-70

73 Vita Iobannis Episcopi Tellae 77. According to John's biographer, Ephrem's supporters had accused him of terrorizing "the Church." 
captivity in Antioch occurred during Ephrem's enkainia (in Syriac: ( אחمسك), or restoration, of the Great Church at Antioch that an earthquake had destroyed in $526 .{ }^{74}$ Ephrem celebrated this enkainia by assembling a council of one hundred and thirty-two bishops, who then excommunicated Severus of Antioch and all his supporters who refused to accept the doctrines of Chalcedon. ${ }^{75}$ Ephrem's role in rebuilding the city and its Great Church was significant in reaffirming his episcopal legitimacy. While Ephrem could claim to be responsible for helping rebuild a city that had been ravaged, perhaps providentially, by the forces of nature, his sympathizers, whether Roman or Persian, ridiculed John for fleeing urban life and for living "in desolate and terrible mountains among lions and wild boars," where he ate animals that only nomads would eat. ${ }^{76}$ At the same time, by rebuilding the Great Church, Ephrem challenged another vital aspect of John's legitimacy as a rival bishop. John's charismatic authority was sustained by his alleged ability to "build" or "edify" a church of the faithful.77 This act of "building" (حس山) was metaphorical; John had not erected a church building, but he had "built" a church of people within frontier territory.

Many textual representations of Ephrem, however, stressed his ability to erect actual buildings, and they suggest that his material structures were generally construed as physical reflections of the church community that he patronized and protected. Ephrem first earned a reputation for restoring both buildings and the communities that they represented when he, as comes Orientis, rebuilt Antioch after the earthquakes of 526 and $528 .{ }^{78}$ His benefactions justified

${ }^{74}$ Vita Iohannis Episcopi Tellae 90.

${ }^{75}$ Historia ecclesiastica Zachariae rhetori vulgo adscripta Vol. 2, 10.5, 190.

76 Vita Iohannis Episcopi Tellae 68. John's association with lions and boars was emphasized by the Persian commander who captured him, but when Ephrem's supporters mocked his alleged camel diet, they were in a similar way indicating that John's retreat into the wilderness did not constitute upright moral or ascetic behavior but savagery.

77 For John's talent for "building" or "edification," as encapsulated by the noun صwr, see Vita Iohannis Episcopi Tellae 36 and 65. Likewise, note the emphasis that John of Tella placed on building in his Statement of Faith, as translated in Menze, Justinian, 90-2.

${ }^{78}$ This episode is stressed by the later writings of John Moschus, Pratum spirituale 37, (PG 87:3, c. 2885-8), who claims that an unknown bishop predicted Ephrem's episcopal tenure as bishop of Antioch when the city's "public buildings were being restored" after one of the earthquakes of the 520 s. His account could very well be derived from a more contemporary perspective that linked Ephrem's episcopal legitimacy in part to his restoration of the city of Antioch. 
his episcopal appointment despite his previous lack of clerical status, and his ability to erect physical buildings correlated easily to his reputation for spiritual edification. He was "the great pillar of the church of the Antiochenes" in both a material and a conceptual sense, and he in turn was known to bring down "heretical" stylites from their columns. ${ }^{79}$ Indeed, Ephrem did not share John's credentials as a self-mortifying ascetic or as a resistor of imperial persecution, but he possessed an official position as bishop of a metropolitan city, his status as a former imperial governor, and the emperor's support. Ephrem's building projects were therefore physical manifestations of these aspects of his identity and authority, and by rebuilding the Great Church and bringing John there to be humiliated, Ephrem was usurping John's status as a "church builder" and stressing that John had no meaningful affiliation with a legitimate episcopal see. ${ }^{80}$ John's church, a disorderly collection of rogues, was no church at all.

Equally as significant, after the earthquake of 528, the emperor Justinian renamed Antioch Theopolis, the city of God. The fact that this event occurred during Ephrem's episcopal tenure suggests that he had some influence on the emperor's decision or that he was at least poised to benefit from it. ${ }^{81}$ The name Theopolis indicated that God himself had re-founded the destroyed city, and accordingly, Ephrem's efforts to rebuild the Great Church were symbolically linked to his reconstruction of "God's polis." At the same time, Ephrem's reconstituted Theopolis was intended to serve as the divinely sanctioned metropolitan city of the Chalcedonian Christians of Syria, and his re-consecration of the Great Church was certainly analogous to his efforts to edify his "orthodox" church community by assembling a council of Syrian bishops that excommunicated

${ }^{79}$ Simeon the Younger is accredited with referring to Ephrem as "the great pillar" when he had a vision about his death. See Vita Simeonis Stylitae Iunioris 71, published in La vie ancienne de Syméon stylite le jeune (521-592), ed. and tr. Paul van den Ven, 2 Vols. SH 32 (Bruxelles: Bollandistes, 196270). According to John Moschus, Pratum spirituale 36, c. 2884-5, Ephrem, through his zeal for the "orthodox faith," persuaded a follower of Severus to dismount his column by throwing into a fire a garment that did not burn.

80 Vita Iohannis Episcopi Tellae 36 and 65.

81 Evagrius Scholasticus, Historia ecclesiastica 4.6, in The Ecclesiastical History of Evagrius, ed. J. Bidez and L. Parmentier (London: Methuen, 1898), 156. Also, Evagrius Scholasticus, Historia Ecclesiastica: Kirchengeschichte, ed. and tr. Adelheid Hübner, Fontes Christiani 57.1-2 (Turnhout: Brepols Publishers 2007), 461-2. 
anti-Chalcedonian "heretics." 82 As a result, the enkainia of the Great Church in Antioch was, judging from Ephrem's conduct, a symbol of victory over the destructive chaos of idolatry. ${ }^{83}$ Because John's "heretical" movement posed a potent danger to what "the city of God" and the restoration of Ephrem's church represented, Ephrem ensured that Severus' excommunication and John's captivity in Antioch occurred during the enkainia festival. John's destruction marked the consummation of Ephrem's efforts to rebuild the Great Church, "the City of God," and an "orthodox" Syria.

Indeed, these elements of Ephrem's ministry indicate why he was so intent to kidnap John from the Persian wilderness and to bring him to Antioch. While his own church, which was sustained by the consensus of a church council and imperial approval, was the ideological center of the Chalcedonian community in Syria, the body and charismatic authority of John, not a building, was the foundation of the politeia of the anti-Chalcedonian faithful. The humiliation of John's flesh was the symbolic antithesis to the rebuilding of Ephrem's church and indisputable evidence of his legitimacy. While sustaining the regional primacy of Antioch, it also marked how Ephrem's Christian community was fundamentally antagonistic to John's church. Ephrem's ecclesiastical community was urban and sustained by Roman imperial support. By contrast, John's consisted of anti-Chalcedonian churchmen and peasants inhabiting imperial margins, and after John's abduction, it had dissolved.

\section{The Destruction OF EpHreM's CHURCH}

Nonetheless, the supremacy of Ephrem's church and what it represented came under close scrutiny in the years directly follow-

${ }^{82}$ John Moschus, Pratum spirituale 37 (PG. 87.3, c. 2888) shows how later generations connected Ephrem's divinely sanctioned efforts to make Antioch, and by extension, Syria into an "orthodox" community with his previous building activities. When Ephrem, as comes Orientis, had been rebuilding the city after the earthquake of 526, an unknown bishop predicted, "God is bringing you onto the apostolic throne of this church of Theopolitans, so that you may shepherd His people...strive for almsgiving and orthodoxy." John Moschus' treatment of Ephrem most likely stems from the ideologies and reputation that the bishop and his supporters had crafted.

${ }^{83}$ For a helpful article on the enkainia festivals in Syria, see Matthew Black, "The Festival of Encaenia Ecclesiae in the Ancient Church with Special Reference to Palestine and Syria" (JEH 5 [London: Faber, 1954]), 78-85. 
ing John's death. Ephrem's triumph was not an enduring one, and his church building was ephemeral. By 540 the Persians had sacked Antioch and had stripped its Great Church of its marbles and its treasures. In fact, the Persians brought the Great Church's treasures and numerous of Antioch's population into "Assyria," and at a site near Ctesiphon, they used such plundered material and captive manpower to establish a new "Antioch." 84 The location of a Roman Antioch on the Mediterranean coast and a Persian Antioch near Ctesiphon could have only further emphasized that the intervening frontier zone was disputed and marginal territory, divided according to the administrative and military capacities of two imperial centers. In response to such calamities, many antiChalcedonians, including Elias, turned to the Old Testament in order to categorize the invasions of 540 and their consequences as God's wrathful punishment for idolatrous behavior, and they imposed the commonplace term "Assyrian" on the Persians in order to draw a connection between the recent invasions and the devastation which an impious Judea had endured in biblical antiquity. ${ }^{85} \mathrm{An}$ anonymous chronicle explicitly stated that God, "who casts judgment in favor of the oppressed," had "incited the Assyrian against him [Ephrem] and the city" in response to the church council through which Ephrem had excommunicated the supporters of Severus of Antioch. ${ }^{86}$ Equally as significant, Elias drew an implicit connection between the destruction of John's ascetic community and the invasions that occurred shortly after by claiming that the "Assyrians" had perpetrated both. The "Assyrian" had sacked both John's monastic settlement at Singara in 537 and his native town of Callinicum in $542 .{ }^{87}$

84 Procopius, de bellis libri 2.9.14-6, 2.14.1-5, ed. Jacob Haury in Procopii Caesariensis opera omnia, Vol. 1 (Leipzig: Teubner, 1905). See Michael G. Morony, "Population Transfers between Sasanian Iran and the Byzantine Empire" in La Persia e Bisanzio (Rome: Accademia Nazionale dei Lincei, 2004), 173-5 for relevant discussion and bibliography.

${ }^{85}$ Historia ecclesiastica Zachariae rhetori vulgo adscripta Vol. 2, 10.5, 190; Vita Iohannis Episcopi Tellae 38. Both authors seemed to be referencing Isa 10:5-6, in which God sends an Assyrian invasion against His rebellious people. Conversely, since the Chalcedonian faction had firm control over Antioch, its proponents were more inclined to blame the attacks on the premise that pagan beliefs still persisted within the city. See Vita Simeonis Stylitae Iunioris 57.

${ }^{86}$ Historia ecclesiastica Zachariae rhetori vulgo adscripta Vol. 2, 10.5, 190.

${ }^{87}$ Vita Iohannis Episcopi Tellae 38-9, 68. The comes of the Persians who led the attack and verbally berated John was referred to as "the Assyrian" (68). As Joel Walker, The Legend of Mar Qardagh: Narrative and Christian 
By linking together the "Assyrian" attacks against John's camp and the "Assyrian" invasions of Syria, the author was able to remind his audience that the abduction of John and the destruction of his ascetic community represented a breach in a divine covenant that was ultimately responsible for the Persian invasions of Roman Syria initiated in 540.88 This perspective had consequential implications. Because Elias had also connected John's divinely sanctioned politeia to the peace that flourished on the frontier, by cooperating to destroy John's community, Ephrem and the Persian Marzban had perpetuated the relentless endeavors of imperial Rome and Persia to affirm contrived political boundaries through military violence. Equally as important, as an exemplar of Roman imperial authority, Ephrem had violated this divinely sanctioned community in an effort to enforce idolatrous and corrupt doctrines, thereby prompting God to punish both the just and the wicked through Persian invasion. ${ }^{89}$ The author was therefore able to attribute the Persian invasions of Roman Syria to Ephrem's villainy and his dissolution of John's spiritual politeia. Ephrem's church, like Justinian's empire, was mired in the corporeal, and it served the corruption of human artifice.

Indeed, the Persian invasions and the destruction of Antioch's Great Church had further importance for the anti-Chalcedonians who endeavored to reconstruct their clerical hierarchy after John's death. Although the rebuilding of the Great Church presumably had spiritual significance for Ephrem and his supporters, the author and likeminded historians inevitably emphasized his church and the imperial regime that sustained it as merely material and ensconced in the corrupt sensory world. An anonymous contemporary author therefore insinuated that Ephrem had rebuilt the Great Church of Antioch with the expectation that his subordinate

Heroism in Late Antique Iraq (Berkeley: University of California, 2006), 249-54 has shown, Assyrian traditions and identities still survived within the region of Adiabene during this period. However, in Elias's case, the use of the term Assyrian most likely follows biblical precedent and refers casually to Persians in general.

${ }^{88}$ In this vein, John of Ephesus, Lives of the Eastern Saints 24, (Life of John of Thella), 319-20 (521-2) noted that the frontier was closed off during the wars of the 540s, and he treated this process as the fulfillment of John's prediction of his own doom and the intensified persecution of those who resisted Chalcedon.

${ }^{89}$ Vita Iohannis Episcopi Tellae 38-9 cites an array of scriptural passages to show that God allowed John's home city Callinicum to be sacked by the Persians in 542 in order to punish both the just and the wicked. 
bishops would grant him gifts before eventually noting that God had destroyed it because of Ephrem's unjust activities. ${ }^{90}$ The perceptions of Ephrem's critics reflect those conveyed decades earlier by a homily that Severus of Antioch had presented at a festival for the enkainia of the Great Church of Antioch, and it is possible that anti-Chalcedonians in Syria were using it to fuel their criticisms. Severus had emphasized to the members of his audience that the festival of enkainia or "renewal" was not celebrated merely to honor the rebuilding of a "visible church" of wood and stone. It was also celebrated to commemorate how they and their predecessors had steered their souls from ancient ignorance and evil toward renewal through faith in Christ. ${ }^{91}$ Anti-Chalcedonians portrayed Ephrem as having violated this principle. Since such a church was void of spirituality, it was thereby bound to be fleeting.

Yet, by contrast, the afflicted remnants of John's church, to whom John's biographer had addressed his Life, had a "founda-

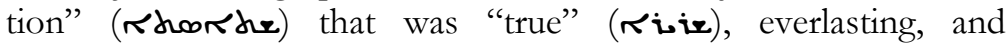
legitimate..$^{22}$ In the wake of John's captivity and death, the pillaging of Antioch and its cathedral therefore seemed to verify the perspectives of many beleaguered anti-Chalcedonians, who saw Ephrem's behavior as both idolatrous and vain. Like the Roman and Persian empires, Ephrem's church had been humanly contrived, and it had been maintained through imperial violence and worldly corruption. Conversely, John's politeia, like that cited in Severus' description of Elijah, had been divinely sanctioned and authentic, and when John of Ephesus cast John in the likeness of the martyr Ignatius, he intimated that John's politeia was the true Antioch, the home of the first community of self-named Christians, whereas Ephrem's Antioch was Rome, a center of imperial oppression. ${ }^{93}$ Such sentiments undoubtedly comforted many anti-Chalcedonians in Syria who would have to wait for the activity of Jacob Baradeus (Bardeàyā) to assume the "pastoral staff" of John of Tella and create a church of "Jacobites" in Syria,

${ }^{90}$ Historia ecclesiastica Zachariae rhetori vulgo adscripta Vol. 2, 10.5, 190.

${ }^{91}$ Severus of Antioch, Homélie 112, in Homiliae cathedrales, ed. Maurice Brière, PO 26 (Paris: Firmin-Didot, 1948) 795-6 [289-90].

92 Vita Iohannis Episcopi Tellae 32.

${ }^{93}$ John of Ephesus, Lives of the Eastern Saints 24 (Life of John of Thella), 514 [312] and 523 [321], citing Ignatius, Romans 5. For Ignatius' imprisonment and martyrdom, see Eusebius, HE 3.26, ed. Eduard Schwartz and Theodor Mommsen, GCS 6.1 (Berlin: Akademie Verlag, 1999). For Antioch as the residence of the first "Christians," see Acts 11:26. 
"Jacobites" in Syria, Armenia, and Persia. ${ }^{94}$ For them, the humiliation of Ephrem's base material church was unavoidable. All sensory beauty, as Elias readily argued, was "like a shadow." 95 It could be gone in an instant.

\section{BIBLIOGRAPHY}

Allen, Pauline and C. T. R. Hayward. Severus of Antioch. London: Routledge, 2004.

Aristotle. Politica, ed. W. D. Ross. Oxford: Clarendon, 1957.

Baum, Wilhelm and Dietmar W. Winkler. The Church of the East: A Concise History. London: RoutledgeCarson, 2003.

Becker, Adam. Fear of God and the Beginning of Wisdom: The School of Nisibis and Christian Scholastic Culture in Late Antique Mesopotamia. Philadelphia: University of Pennsylvania, 2006.

The Biography of John of Tella by Elias, tr. J. R. Ghanem. Diss. University of Wisconsin, 1970.

Black, Matthew. "The Festival of Encaenia Ecclesiae in the Ancient Church with Special Reference to Palestine and Syria." JEH 5 (1954): 78-85.

Brock, Sebastian. "Christians in the Sasanian Empire: A Case of Divided Loyalties." In Religion and National Identity, Studies for Church History 18, 1-19. Oxford: Blackwell, 1982.

"The Christology of the Church of the East in the Synods of the Fifth to the Early Seventh Centuries." In Aksum-Thyateira, a Festschrift for Archbishop Methodius of Thyateira and Great Britain, ed. G. Dragas, 125-42. London: Thyateira House, 1985.

"The Conversations with the Syrian Orthodox under Justinian (532)." OrChrP 47 (1981): 87-121.

"Greek and Syriac in Late Antique Syria." In Literacy and Power in the Ancient World, ed. Alan K. Bowman and Greg Woolf, 14960. Cambridge: Cambridge University Press, 1994.

"The 'Nestorian' Church: A Lamentable Misnomer." BJRL 78.3 (1996): 23-36.

Chesnut, Roberta. Three Monophysite Christologies: Severus of Antioch, Philoxenus of Mabbug, and Jacob of Sarug. Oxford: Oxford University Press, 1976.

Cyril of Alexandria. Epistulae, ed. Migne in PG 77: 1-390.

Drijvers, Han J. W. "Bardaisan von Edessa als Repräsentant des syrischen Synkretismus im 2. Jahrhundert n. Chr." In Synkretismus im syrisch-

94 The Spurious Life of James, ed. and tr. E. W. Brooks in John of Ephusus' Lives, PO 19 (Paris: Firmin-Didot, 1921), 236 [582] and 256 [602]. This life presents much of the material of John of Ephesus' Life of James and Life of James and Theodore, and it therefore reflects a later interpretation of Jacob's activity.

95 Vita Iohannis Episcopi Tellae 41. 
persischen Kulturgebiet, ed. A. Dietrich, 109-22. Göttingen: Symposion, 1971.

Eusebius, Historia ecclesiastica, ed. Eduard Schwartz and Theodor Mommsen in Die Kirchengeschichte, GCS 6.1-3. Berlin: Akademie Verlag, 1999.

De martyribus Palaestinae, ed. Eduard Schwartz and Theodor Mommsen in Die Kirchengeschichte, GCS 6.2. Berlin: Akademie Verlag, 1999.

Evagrius. Historia ecclesiastica, ed. J. Bidez and L. Parmentier in The Ecclesiastical History of Evagrius. London: Methuen, 1898 and Adelheid Hübner in Evagrius Scholasticus, Historia Ecclesiastica: Kirchengeschichte, Fontes Christiani 57.1-2. Turnhout: Brepols Publishers, 2007.

Fowden, Elizabeth Key. The Barbarian Plain: Saint Sergius between Rome and Iran. Berkeley: University of California Press, 1999.

Frend, W. H. C. The Rise of the Monophysite Movement: Chapters in the History of the Church in the Fifth and Sixth Centuries. $2^{\text {nd }}$ ed. Cambridge: Cambridge University Press, 1979.

Gray, Patrick. The Defense of Chalcedon in the East (451-553). Leiden: Brill, 1979

Greatrex, Geoffrey. "Byzantium and the East in the Sixth Century." In The Cambridge Companion to the Age of Justinian, ed. Michael Maas, 477-509. Cambridge: Cambridge University Press, 2005.

Gregory of Nazianzus. Orationes, ed. Migne in PG 35-6, 393-1252, 62665.

Grünewald, Thomas. Bandits in the Roman Empire: Myth and Reality. Tr. John Drinkwater. London: Routledge, 2004.

Harvey, Susan Ashbrook. Asceticism and Society in Crisis: John of Ephesus and the Lives of the Eastern Saints. Berkeley: University of California Press, 1990.

Historia ecclesiastica Zachariae rhetori vulgo adscripta, ed. E. W. Brooks, CSCO III 5-6. Paris: E Typographeo Reipublicae, 1919-21.

Honigmann, E. Évêques et évêchés Monophysites d'Asie antérieure au VTe siècle, CSCO 127/Subsidia 2. Louvain: Secrétariat du CorpusSCO, 1951.

Humfress, Caroline. "Law and Legal Practice in the Age of Justinian." In The Cambridge Companion to the Age of Justinian, ed. Michael Maas, 161-84. Cambridge: Cambridge University Press, 2005.

John Chrysostom. In Jo., ed. Migne in PG 59: 1-482. In Matt., ed. Migne in PG 57-8.

John of Ephesus. Iohannis Ephesini historiae ecclesiasticae pars tertia, ed. and tr. E. W. Brooks, CSCO, Scriptores Syri 54-55 (Series 3, T and V 3). Louvain: Imprimerie Orientaliste, 1952.

Lives of the Eastern Saints, ed. and tr. by E. W. Brooks, PO 1719. Paris: Firmin-Didot, 1923-5: 1-310, 513-698, 153-285.

John Moschus. Pratum spirituale, ed. Migne in PG 87:3: 2852-3112.

John of Tella (bar Qursus). Canons, ed. and tr. Arthur Vööbus in The Synodicon in the West Syrian Tradition, CSCO 367-8, Scriptores Syri 
161-2. Louvain: Secrétariat du CorpusSCO, 1975: 145-56 (14251)

Questions and Answers, ed. and tr. Arthur Vööbus in The Synodicon in the West Syrian Tradition, CSCO 367-8, Scriptores Syri 161-2. Louvain: Secrétariat du CorpusSCO, 1975: 211-21 (197-205).

Statement of Faith, ed. and tr. Kutlu Akalin and Volker Menze in John of Tella's Statement of Faith, TeCLA. Piscataway, NJ: Gorgias Press, forthcoming.

Josephus. Antiquitates Judaicae. ed. Benedict Niese in Flavii Josephi opera, Vols. 1-4. Berlin: Teubner, 1887-90.

Contra Apionem., ed. Benedict Niese in Flavii Josephi opera, Vol. 4. Berlin: Teubner, 1890.

Justin Martyr. Apologia maior, ed. Miroslav Marcovich in Justini Martyris apologiae pro Christianis, Patristische Texte und Studien, Vol. 38. Berlin: de Gruyter, 1994.

Liebeschuetz, J. H. W. G. The Decline and Fall of the Ancient City. Oxford: Oxford University Press, 2000.

Menze, Volker. Justinian and the Making of the Syrian Orthodox Church. Oxford: Oxford University Press, 2008.

"Priests, Laity, and the Sacrament of the Eucharist in SixthCentury Syria." Hugoye: Journal of Syriac Studies 7.2 (2004): pars. 121.

"The Regula ad Diaconos: John of Tella, his Eucharistic Ecclesiology, and the Establishment of an Ecclesiastical Hierarchy in Exile." OrChr 90 (2006): 44-90.

Millar, Fergus. The Greek Roman Empire: Power and Belief under Theodosius II (408-450). Berkeley: University of California Press, 2006.

Morony, Michael G. "Population Transfers between Sasanian Iran and the Byzantine Empire." In La Persia e Bisanzio: Atti del Convegno internazionale (Roma, 14-18 ottobre 2002), 161-79. Rome: Accademia Nazionale dei Lincei, 2004.

Nau, F. Textes Monophysites, PO 13. Paris: Firmin-Didot, 1919: 161-269.

Novum Testamentum Graece et Latine. Ed. Barbara and Kurt Aland. Stuttgart: Deutsche Bibelgesellschaft, 1984.

Palladius. Historia Lausiaca, ed. Cuthbert Butler in The Lausiac History of Palladius, Vol. 2. Cambridge: Cambridge University Press, 18981904.

Palmer, Andrew. "Saints' Lives with a Difference: Elijah on John of Tella (d. 538) and Josephus on Theodotos of Amida (d. 698)." In IV Symposium Syriacum 1984: Literary Genres in Syriac Literature, ed. H. J. W. Drijvers et al., 203-16. Orientalia Christiana Analecta 229. Roma: Pont. Institutum, 1987.

Plato. Respublica, ed. S. R. Slings. Oxford: Clarendon, 2003.

Procopius. De bellis libri, ed. Jacob Haury in Procopii Caesariensis opera omnia, Vol. 1. Leipzig: Teubner, 1905.

Segal, J. B. "Mesopotamian Communities from Julian to the Rise of Islam." PBA 41 (1955): 109-40. 
Severus of Antioch. Homiliae cathedrales LXXXIV-XC and CXX-CXXV, ed. and tr. Maurice Brière, PO 23 and 26. Paris: Firmin-Didot, 1932 and 1948: 1-176 and 259-450.

The Sixth Book of the Select Letters of Severus, Patriarch of Antioch, ed. and tr. by E. W. Brooks, 4 Vols. London: Williams \& Norgate, 1904.

Shahîd, Irfan. Byzantium and the Arabs in the Sixth Century, 2 Vols. Washington: Dumbarton Oaks, 1995.

Shaw, Brent. "Bandits in the Roman Empire." Past and Present 105 (1984): 3-52.

"'Eaters of Flesh, Drinkers of Milk': The Ancient Mediterranean Ideology of the Pastoral Nomad." Ancient Society 13-14 (1982/3): 5-31.

The Syrian Chronicle Known as that of Zachariah of Mitylene, tr. F. J. Hamilton and E. W. Brooks. London: Methuen \& Co., 1899.

Tatian. Oratio ad Graecos, ed. Miroslav Marcovich, Patristische Texte und Studien, Vol. 43. Berlin: de Gruyter, 1995.

Taylor, David G. K. "Bilingualism and Diglossia in Late Antique Syria and Mesopotamia." In Bilingualism in Ancient Society: Language Contact and the Written Text, ed. J. N. Adams, Mark Janse, and Simon Swain, 298-331. Oxford: Oxford University Press, 2002.

Tetraenangelium Sanctum juxta simplicem Syrorum versionem ad fidem codicum, massorae, editionum denuo regcognitum, ed. P. E. Pusey and G. H. Gwilliam. Oxford: Clarendon Press, 1901.

Theodoret. Historia religiosa, ed. Pierre Canivet et Alice Leroy-Molinghen, Histoire des moines de Syrie, Vol. 1. SC 234. Paris: Cerf, 1977.

Van Rompay, Lucas. "Society and Community in the Christian East." In The Cambridge Companion to the Age of Justinian, ed. Michael Maas. 239-66. Cambridge: Cambridge University Press, 2005.

Vita Iohannis Episcopi Tellae, ed. and tr. by E. W. Brooks in Vitae virorum apud Monophysitas CSCO III 25 (7-8). Paris: E Typographeo Reipublicae, 1907: 29-95 and 21-60.

Vita Simeonis Stylitae Iunioris. In La vie ancienne de Syméon stylite le jeune (521592), ed. and tr. Paul van den Ven, 2 Vols. SH 32. Bruxelles: Bollandistes, 1962-70.

Walker, Joel. The Legend of Mar Qardagh: Narrative and Christian Heroism in Late Antique Iraq. Berkeley: University of California Press, 2006. 